\title{
SISTEM PENDUKUNG KEPUTUSAN MENGGUNAKAN METODE PROMETHEE (STUDI KASUS : STASIUN PENGISIAN BAHAN BAKAR UMUM)
}

\author{
Bambang Yuwono, Frans Richard Kodong, Hendy Ayusta Yudha \\ Jurusan Teknik Informatika UPN "Veteran" Yogyakarta \\ Jl. Babarsari 2 Tambakbayan 55281 Telp (0274) 485323 \\ e-mail : bambangy@gmail.com, frkodong@gmail.com
}

\begin{abstract}
The research was conducted based on the need for assistive devices for people to determine the location of the establishment of public refueling stations. Aids in the form of decision support systems. There are six criteria for determining the location of the establishment of broad land, land prices, traffic density, many transportation routes, distance to other retail outlets and administration. While the location is also six. In this study has successfully built a decision support system to determine the location of the establishment of public refueling stations using the method promethee. Hasi of this system of ranking based on the size of the leaving flow, entering flow, and net flow.

Keywords: Decision Support Systems, Promethee, SPBU

Penelitian ini dilakukan berdasarkan kebutuhan akan adanya alat bantu bagi seseorang untuk menentukan lokasi pendirian stasiun pengisian bahan bakar umum. Alat bantu tersebut berupa sistem pendukung keputusan. Ada enam kriteria untuk menentukan lokasi pendirian yaitu luas tanah,harga tanah,kepadatan lalu lintas, banyak jalur angkutan, jarak dengan SPBU lain dan administrasi. Sedangkan lokasinya juga ada enam. Pada penelitian ini telah berhasil dibangun sebuah sistem pendukung keputusan untuk menentukan lokasi pendirian stasiun pengisian bahan bakar umum menggunakan metode promethee. Hasi dari sistem ini berupa rangking berdasarkan ukuran leaving flow, entering flow, dan net flow.

Kata kunci : Sistem Pendukung Keputusan, Promethee, SPBU
\end{abstract}

\section{PENDAHULUAN}

Kendaraan bermotor sebagai alat transportasi sangat membutuhkan bahan bakar sebagai kebutuhan pokoknya. Jumlah kendaraan yang semakin meningkat, tentu saja berakibat pada meningkatnya permintaan pasar untuk bahan bakar kendaraan. Untuk memenuhi banyaknya kebutuhan bahan bakar kendaraan maka diharapkan persebaran lokasi stasiun pengisian bahan bakar umum dapat merata sesuai kebutuhan konsumen.

Seorang yang ingin mendirikan sebuah Stasiun Pengisian Bahan Bakar Umum (SPBU), dalam menentukan lokasi stasiun pengisian bakar umum memerlukan banyak pertimbangan untuk mengambil keputusan lokasi yang cocok dan strategis sebagai tempat stasiun pengisian bahan bakar umum. Pertimbangan dalam melakukan pemilihan lokasi stasiun pengisian bahan bakar umum diantaranya adalah luas lahan, harga tanah, administrasi, jarak dari pusat kota, kepadatan penduduk, tingkat perekonomian penduduk sekitar, kepadatan lalu lintas, banyaknya jalur angkutan umum, dan jarak dengan stasiun pengisian bahan bakar umum lainnya.

Mempertimbangkan kondisi yang ada maka diperlukan Sistem Pendukung Keputusan berbasis komputer, sistem ini adalah suatu sistem berbasis komputer yang dirancang untuk meningkatkan efektifitas pengambil keputusan dalam memecahkan masalah.

\section{TINJAUAN PUSTAKA}

\subsection{Sistem Pendukung Keputusan}

Sistem Pendukung Keputusan (SPK)/ Decision Support System (DSS) pertama kali diungkapkan pada awal tahun 1970-an oleh Michael S. Scott Morton dengan istilah Manajement Decision Systems (Daihani, 2001). Selanjutnya, sejumlah perusahaan, lembaga 
penelitian dan perguruan tinggi mulai melakukan penelitian dan membangun SPK. Sistem ini merupakan suatu sistem yang berbasis komputer yang ditujukan untuk membantu pengambil keputusan dalam memanfaatkan data dan model tertentu untuk memecahkan berbagai persoalan yang bersifat semi terstruktur dan tidak terstruktur.

Sistem pendukung keputusan mempunyai 3 komponen utama yaitu :

a) Subsistem manajemen data/basis data.

b) Subsistem manajemen model/basis model.

c) Subsistem penyelenggara dialog.

\subsection{PROMETHEE (Preference Ranking Organizational Method for Enrichment Evaluation)}

Promethee adalah suatu metode penentuan urutan (prioritas) dalam analisis multikriteria. Masalah pokoknya adalah kesederhanaan, kejelasan, dan kestabilan. Dugaan dari dominasasi kriteria yang digunakan dalam Promethee adalah penggunaan nilai dalam hubungan outrangking. Semua parameter yang dinyatakan mempunyai pengaruh nyata menurut pandangan ekonomi (Brans et. al, 1986).

Promethee menyediakan kepada user untuk menggunakan data secara langsung dalam bentuk tabel multikriteria sederhana. Promethee mempunyai kemampuan untuk menangani banyak perbandingan, pengambil keputusan hanya mendefenisikan skala ukurannya sendiri tanpa batasan, untuk mengindikasi prioritasnya dan preferensi untuk setiap kriteria dengan memusatkan pada nilai (value), tanpa memikirkan tentang metode perhitungannya.

Metode Promethee menggunakan kriteria dan bobot dari masing-masing kriteria yang kemudian diolah untuk menentukan pemilihan alernatif lapangan, yang hasilnya berurutan berdasarkan prioritasnya.

Penggunaan metode Promethee dapat dijadikan metode untuk pengambilan keputusan di bidang pemasaran, sumber daya manusia, pemilihan lokasi, atau bidang lain yang berhubungan dengan pemilihan alternatif.

\section{Fungsi Preferensi}

Dalam promethee disajikan enam bentuk fungsi preferensi kriteria. Hal ini tentu saja tidak mutlak, tetapi bentuk ini cukup baik untuk beberapa kasus.

Untuk memberikan gambaran yang lebih baik terhadap area yang tidak sama, digunakan fungsi selisih nilai kriteria antara alternative $H(d)$ dimana hal ini mempunyai hubungan langsung pada fungsi preferensi P.

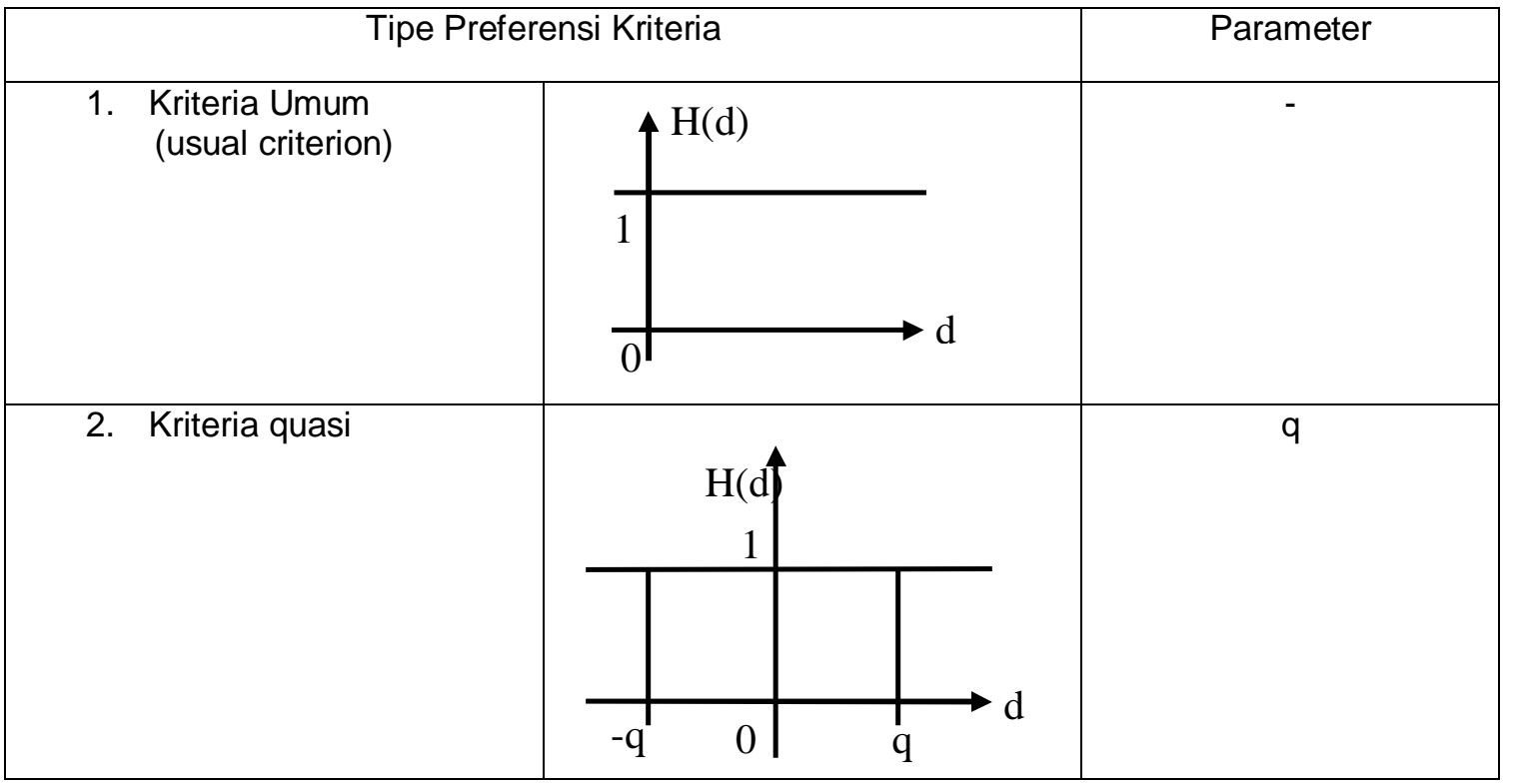




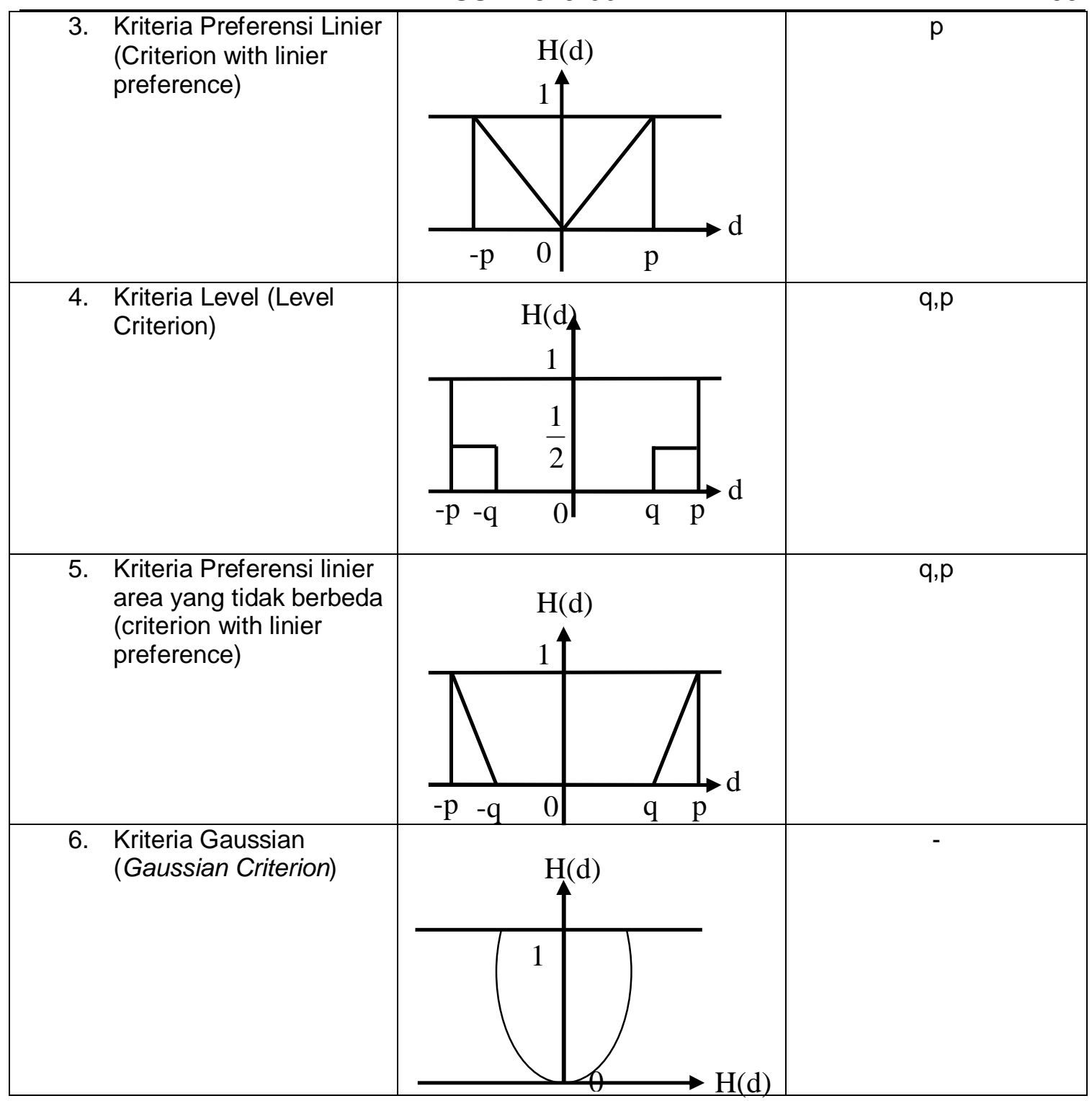

\section{Analisis dan Perancangan Sistem}

Seorang manajer stasiun pengisian bahan bakar umum sering kali mengalami kesulitan dalam mendapatkan keputusan untuk memilih lokasi yang cocok dan strategis sebagai lokasi pembangunan stasiun pengisian bahan bakar umum. Untuk membantu memecahkan masalah itu maka dibuatlah suatu sistem pendukung keputusan untuk memilih lokasi dengan menggunkan metode promethee.

Adapun kriteria-kriteria yang ditetapkan oleh seorang manajer stasiun pengisian bahan bakar umum sebagai lokasi pembangunan stasiun pengisian bahan bakar umum adalah :

1. Luas tanah

2. Harga tanah

3. Kepadatan lalu lintas

4. Banyak jalur angkutan

5. Jarak dengan SPBU lain

6. Administrasi.

Untuk menemukan jalan keluar bagi seorang manajer stasiun pengisian bahan bakar umum maka dibuat suatu sistem yang dapat menentukan urutan (prioritas) dalam analisis multikriteria dan memberikan informasi lokasi pembangunan stasiun pengisian bahan bakar umum yang akan di bangun stasiun pengisian bahan bakar umum dan menentukan urutan berdasarkan kriteria yang ditentukan oleh seorang manajer. 


\section{Spesifikasi Sistem}

Aplikasi sistem pendukung keputusan dengan metode Promethee (Studi Kasus : Stasiun Pengisian Bahan Bakar Umum) ini memiliki spesifikasi sebagai berikut :

1. Sistem memberikan fasilitas untuk pengaturan data pengguna sistem.

2. Sistem memberikan fasilitas untuk input daerah atau tempat, input kriteria, dan input data preferensi.

3. Sistem memberikan fasilitas untuk pengelolaan data pemilihan lokasi pembangunan stasiun pengisian bahan bakar umum seperti menambah data, mengubah dan menghapus data.

4. Sistem memberikan fasilitas untuk menghitung ulang kualitas layanan.

5. Sistem mampu untuk menampilkan data preferensi, data nilai prioritas serta data nilai konsistensi.

\section{Rancangan Model}

Untuk masalah pengukuran serta perbandingan kualitas layanan, dimensi yang digunakan sebagai kriteria meliputi luas tanah, harga tanah, kepadatan lalu lintas, banyak, jalur angkutan, jarak dengan SPBU dengan lokasi, dan administrasi. Simbol yang di gunakan untuk kriteria tersebut adalah :
$\mathrm{K} 1$ : Luas tanah
K2 : Harga tanah
K3 : Kepadatan Ialu lintas
$\mathrm{K} 4$ : Banyak jalur angkutan
$\mathrm{K} 5$ : Jarak dengan SPBU lainnya
K6 : Administrasi

Simbol Alternatif atau alternatif yang digunakan adalah :
A1 : Jalan Kotabaru
A2 : Jalan Sungai Raya
A3 : Jalan Pancasila
A4 : Jalan Siantan
A5 : Jalan Podomoro
A6 : Jalan Supadio
LF : Leaving flow
EF : Entering flow
NF : Net flow

Simbol hasil perhitungan :

Berdasarkan survey yang telah dilakukan, dan berdasarkan brosur pertamina pada januari 2010 yang memberikan skala penilaian dengan menggunakan skala perbandingan persentasi, interval, dan kondisi yang berdasarkan 4 golongan, golongan tersebut mempunyai range masing-masing yaitu: golongan 1 lebih besar prioritasnya dari pada golongan yang lainnya dan seterusnya, di dalam golongan tersebut terdapat batasan penilaian untuk masingmasing sub-sub kriteria dan memberikan tingkatan atau keadaan setiap golongannya. Untuk menentukan hasil penelitian masing-masing sub-sub kriteria dapat di lihat pada tabel 3.1 dan tabel 3.2

Tabel 3.1 Nilai Kriteria

\begin{tabular}{|c|c|c|c|c|}
\hline \multirow{2}{*}{ LUAS TANAH } & \multicolumn{4}{|c|}{ GOLONGAN } \\
\hline & 1 & II & III & IV \\
\hline Luas $\left(m^{2}\right)$ & $1700-2500$ & $1325-1600$ & $1000-1225$ & $700-900$ \\
\hline \multirow{2}{*}{ HARGA TANAH } & \multicolumn{4}{|c|}{ GOLONGAN } \\
\hline & 1 & II & III & IV \\
\hline Harga $\left(R p / m^{2}\right)$ & $0 ;-50.000$ & $\begin{array}{l}51.000 ;- \\
75.000\end{array}$ & $\begin{array}{l}\text { 76.000;- } \\
\text { 100.000; }\end{array}$ & $\begin{array}{l}110.000 ;- \\
\text { lebih }\end{array}$ \\
\hline \multirow{2}{*}{ KEPADATAN LALU LINTAS } & \multicolumn{4}{|c|}{ GOLONGAN } \\
\hline & 1 & II & III & IV \\
\hline $\begin{array}{l}\text { Angkutan umum kota } \\
\text { (kendaraan/jam) }\end{array}$ & 6-lebih & $3-4$ & $1-2$ & 0 \\
\hline $\begin{array}{l}\text { Angkutan umum antar kota } \\
\text { (kendaraan/jam) }\end{array}$ & 5-lebih & $3-4$ & $1-2$ & 0 \\
\hline Sepeda motor (kendaraanjam) & 30-lebih & $16-29$ & $1-15$ & 0 \\
\hline
\end{tabular}


TELEMATIKA

ISSN 1829-667X

\begin{tabular}{|c|c|c|c|c|}
\hline Mobil pribadi (kendaraan/jam) & 20-lebih & $11-19$ & $1-10$ & 0 \\
\hline \multirow{2}{*}{ BANYAK JALUR ANGKUTAN } & \multicolumn{4}{|c|}{ GOLONGAN } \\
\hline & 1 & II & III & IV \\
\hline Angkutan umum (jalur) & 5-lebih & $4-3$ & $2-1$ & 0 \\
\hline \multirow{2}{*}{ JARAK DENGAN SPBU LAIN } & \multicolumn{4}{|c|}{ GOLONGAN } \\
\hline & 1 & II & III & IV \\
\hline Jarak (km) & 10-lebih & $7-10$ & $5-9$ & $0-4$ \\
\hline ADMINISTRASI & \multicolumn{4}{|c|}{ GOLONGAN } \\
\hline FEIVIIVIOI IRAOS & 1 & II & III & IV \\
\hline Surat menyurat & Sangat Baik & Baik & Cukup & Buruk \\
\hline
\end{tabular}

*sumber : Surat Kabar Pontianak Post \& Brosur Pertamina

Nilai masukan sebenarnya di dapatkan dari hasil masukan seluruh data dari tabel kondisi lokasi untuk stasiun pengisian bahan bakar umum. Perbandingan kriteria yang di modelkan dengan menggunakan metode pengembangan promethee. Perbandingan nilai kriteria berdasarkan golongan setiap kriteria, nilai setiap kriteria berdasarkan jumlah semua nilai sub-sub masing-masing kriteria. Jumlah nilai masing-masing kriteria akan menjadi nilai perhitungan dalam menentukan alternatif rangking.

Dalam model ini, setiap sub kriteria akan memiliki nilai masukan yang telah ditentukan sebelumnya berdasarkan golongannya.

Tabel 3.2 Potensi SPBU Berdasarkan Golongan

\begin{tabular}{|c|c|c|c|c|}
\hline \multirow{2}{*}{ KRITERIA } & \multicolumn{4}{|c|}{ GOLONGAN } \\
\cline { 2 - 5 } & $\mathrm{I}$ & $\mathrm{II}$ & $\mathrm{III}$ & $\mathrm{IV}$ \\
\hline LUAS TANAH & $2500 \mathrm{~m}^{2}$ & $1600 \mathrm{~m}^{2}$ & $1225 \mathrm{~m}^{2}$ & $900 \mathrm{~m}^{2}$ \\
\hline HARGA TANAH & $\mathrm{Rp} 25.000 ; \mathrm{m}^{2}$ & $\mathrm{Rp} 50.000 ; / \mathrm{m}^{2}$ & $\mathrm{Rp} 75.000 ; \mathrm{m}^{2}$ & $\mathrm{Rp} 110.000 ; / \mathrm{m}^{2}$ \\
\hline $\begin{array}{c}\text { KEPADATAN } \\
\text { LALU LINTAS }\end{array}$ & $\begin{array}{c}90 \\
\text { kendaraan/jam }\end{array}$ & $\begin{array}{c}75 \\
\text { kendaraan/jam }\end{array}$ & $\begin{array}{c}44 \\
\text { kendaraan/jam }\end{array}$ & 0 kendaraan/jam \\
\hline $\begin{array}{c}\text { BANYAK } \\
\text { JALUR } \\
\text { ANGKUTAN }\end{array}$ & 8 jalur & 6 jalur & 2 jalur & 0 jalur \\
\hline $\begin{array}{c}\text { JARAK } \\
\text { DENGAN SPBU } \\
\text { LAIN }\end{array}$ & $10 \mathrm{~km} / \mathrm{jam}$ & $5,5 \mathrm{~km} / \mathrm{jam}$ & $5,4 \mathrm{~km} / \mathrm{jam}$ & $0 \mathrm{~km} / \mathrm{jam}$ \\
\hline \begin{tabular}{c} 
ADMINISTRASI \\
\hline
\end{tabular} & $100 \%$ & $50 \%$ & $25 \%$ & $0 \%$ \\
\hline
\end{tabular}

*sumber : Surat Kabar Pontianak Post \& Brosur Pertamina

Dari tabel tersebut maka didapat nilai masing-masing Golongan adalah :

Golongan I $=(40,1 \%+9,6 \%+43 \%+50 \%+47,8 \%+100 \%)=290,5$

Golongan II $=(25,7 \%+19,2 \%+35,8 \%+37,5 \%+26,3 \%+50 \%)=194,5$

Golongan III $=(19,6 \%+28,8 \%+21 \%+12,5 \%+25,8 \%+25 \%)=132,7$

Golongan IV $=(14,4 \%+42,4 \%+0 \%+0 \%+0 \%+0 \%)=56,8$

Untuk menentukan nilai bobot masing-masing golongan adalah :

a. Nilai masukan pada Golongan I diperoleh jika nilai rata-rata : $(290,5 / 674,5) \times 100=43,1 \%$

b. Nilai masukan pada Golongan II diperoleh jika nilai rata-rata : $(194,5 / 674,5) \times 100=28,8 \%$

c. Nilai masukan pada Golongan III diperoleh jika nilai rata-rata : $(132,7 / 674,5) \times 100=19,7 \%$

d. Nilai masukan pada Golongan IV diperoleh jika nilai rata-rata : $(56,8 / 674,5) \times 100=8,4 \%$

Dari rancangan nilai yang telah dibuat, maka didapat beberapa lokasi pembangunan stasiun pengisian bahan bakar umum yang nantinya akan dicari lokasi pembangunan stasiun pengisian bahan bakar umum yang terbaik atau mengurutkan lokasi pembangunan stasiun 
pengisian bahan bakar umum yang lebih baik. Untuk menentukan urutan atau lokasi pembangunan stasiun pengisian bahan bakar umum mana yang terbaik maka diperlukan perhitungan perbandingan dengan menentukan nilai-nilai perhitungan, Tahapan perhitungan adalah :

Fase pertama, nilai hubungan outrangking berdasarkan pertimbangan dominasi masingmasing kriteria. Indeks preferensi ditentukan dan nilai outrangking secra grafis disajikan berdasarkan preferensi dari pembuat keputusan. Data dasar untuk evalusi dengan metode promethee disajikan sebagai berikut :

Tabel 3.3 Data Dasar Analisis Promethee

\begin{tabular}{|c|c|c|c|c|c|c|c|c|c|c|}
\hline \multirow{2}{*}{ 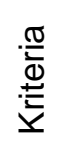 } & \multirow{2}{*}{$\begin{array}{l}\text { Min } \\
\text { Max }\end{array}$} & \multicolumn{6}{|c|}{ Alternatif } & \multirow{2}{*}{ LF } & \multirow{2}{*}{ EF } & \multirow{2}{*}{ NF } \\
\hline & & A1 & A2 & A3 & A4 & A5 & A6 & & & \\
\hline K1 & Min & $\mathrm{K} 1(\mathrm{~A} 1)$ & K1(A2) & K1(A3) & K1(A4) & K1(A5) & K1(A6) & & & \\
\hline K2 & Max & K2(A1) & $\mathrm{K} 2(\mathrm{~A} 2)$ & K2(A3) & K2(A4) & K2(A5) & K2(A6) & & & \\
\hline K3 & Max & K3(A1) & $\mathrm{K} 3(\mathrm{~A} 2)$ & K3(A3) & K3(A4) & K3(A5) & K3(A6) & & & \\
\hline K4 & Max & K4(A1) & $\mathrm{K} 4(\mathrm{~A} 2)$ & K4(A3) & K4(A4) & K4(A5) & K4(A6) & & & \\
\hline K5 & Max & $\mathrm{K} 5(\mathrm{~A} 1)$ & $\mathrm{K} 5(\mathrm{~A} 2)$ & K5(A3) & K5(A4) & K5(A5) & K5(A6) & & & \\
\hline K6 & Max & K6(A1) & $\mathrm{K} 6(\mathrm{~A} 2)$ & K6(A3) & K6(A4) & K6(A5) & K6(A6) & & & \\
\hline
\end{tabular}

*sumber : Sistem Pendukung Keputusan, Kadarsah, 1998

Berikut ini merupakan penjelasan dari istilah atau singkatan yang digunakan :

1. $\mathrm{K} 1(\mathrm{~A} 1)$ : Elemen matrik $\mathrm{K} 1$ baris ke 1 dan kolom ke 1

2. $\mathrm{K} 1(\mathrm{~A} 2)$ : Elemen matrik $\mathrm{K} 1$ baris ke 1 dan kolom ke 2

3. $\mathrm{K}_{\mathrm{mn}}$ : Elemen matrik $\mathrm{K}$ baris ke $\mathrm{m}$ dan kolom ke $\mathrm{n}$

Berdasarkan tabel data diatas maka untuk mencari nilai arah dalam persentase outrangking, dengan menggunakan :

1. Jumlah dari nilai garis lengkungan yang memiliki arah menjauh dari node a lebih baik dari $x$ (leaving flow).

2. Diukur berdasarkan karakter outrangking dari nilai a (entering flow)

3. Menentukan perbandingan urutan nilai yang terbaik atau rangking dari lokasi pembangunan stasiun pengisian bahan bakar umum (net flow).

Seperti yang telah diketahui bahwa nilai yang dimasukan ke dalam matrik merupakan nilai perbandingan berpasangan dimana nilai elemen $\mathrm{K}_{\mathrm{mn}}$ merupakan nilai kebalikan dari elemen $\mathrm{K}_{\mathrm{nm}}$. Sedangkan untuk elemen matrik yang memiliki nomor baris dan kolom yang sama, misalnya elemen matrik M baris ke 1 dan kolom ke 1 akan bernilai 1 (satu). Hal ini dapat terjadi karena elemen matrik yang memiliki baris dan kolom yang sama hanyalah membandingkan kriteria yang sama. Dengan demikian, pengguna atau user aplikasi ini yaitu admin tidak perlu memasukkan seluruh nilai elemen matrik.

Fase kedua, dalam proses penentuan prioritas adalah menjumlahkan nilai dari setiap kolom matrik. Aturan yang dapat dipakai sebagai berikut :

Sebelum menghitung nilai setiap kolom maka kata harus menentukan daerah mana yang akan dibandingkan :

Tahap I:

Tahap II :

Daerah A1 di bandingkan dengan daerah A2

Untuk K1

Tahap III :

$$
\mathrm{d}=\mathrm{A} 1-\mathrm{A} 2
$$

kemudian menentukan kaidah yang digunakan, yaitu maksimasi atau minimasi

$P(A 1, A$ 2) $=a$

Tahap IV :

$\mathrm{P}(\mathrm{A} 2, \mathrm{~A} 1)=\mathrm{b}$

Menghitung semua nilai yang terdapat :

$$
\begin{aligned}
& \wp(\mathrm{A} 1, \mathrm{~A} 2)=1 / 6 * \sum(A 1, A 2) \\
& \wp \mathrm{P}(\mathrm{A} 2, \mathrm{~A} 1)=1 / 6^{*} \sum(A 2, A 1)
\end{aligned}
$$




$$
\begin{aligned}
& \text { leaving flow : } \Phi^{+}(\mathrm{a})=\frac{1}{\mathrm{n}-1} \sum_{\mathrm{x} \varepsilon \mathrm{A}} \wp(\mathrm{a}, \mathrm{x}) \\
& \text { entering flow : } \Phi^{-}(\mathrm{a})=\frac{1}{\mathrm{n}-1} \sum_{\mathrm{x} \varepsilon \mathrm{A}} \wp(\mathrm{x}, \mathrm{a}) \\
& \text { net flow: } \Phi^{+}(\mathrm{a})-\Phi^{-}(\mathrm{a})
\end{aligned}
$$

\section{HASIL DAN PEMBAHASAN}

\section{Halaman home}

Halaman home/index merupakan halaman yang pertama kali dibuka oleh user. Pada halaman ini, dibuat dengan teknik frame dengan pemunculan langsung halaman home. Maksudnya adalah apabila user masuk ke halaman web ini, maka user akan langsung dihadapkan oleh halaman home. Di halaman home, terdapat pilihan untuk login, untuk melihat data survey, memilih kriteria yang diinginkan, melihat data flow, melakukan pencarian, melihat help, dan login. Login diperuntukkan bagi admin, sedangkan perintah lainnya sebagai pengunjung yang dapat menggunakan sesui dengan keinginan dan data atau fasilitas yang ada pada home interface tersebut.

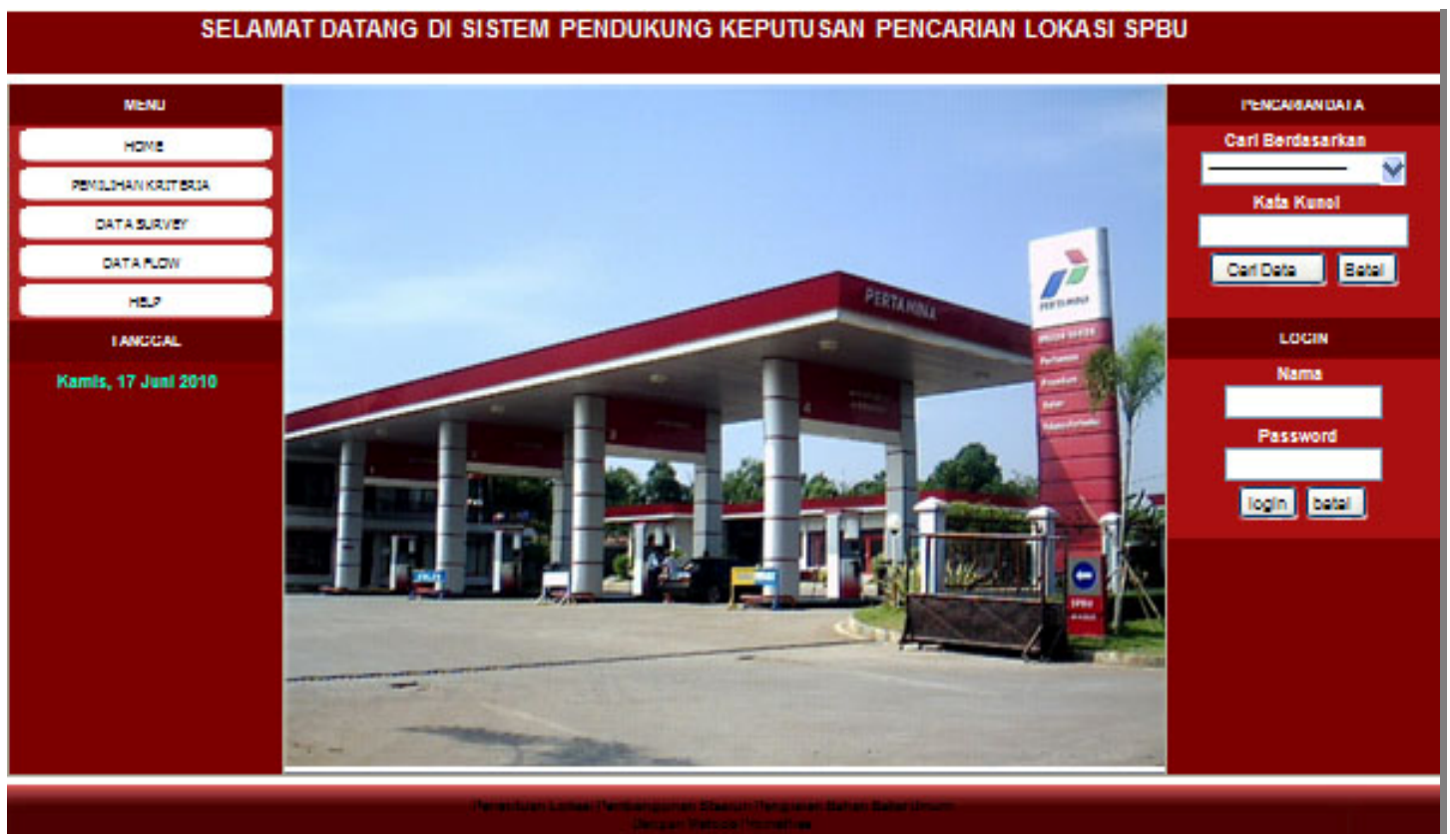

Gambar 4.1 Halaman Home

\section{Halaman pilihan Kriteria}

Halaman Pilihan Kriteria adalah halaman yang digunakan untuk memilih data kriteria yang akan dibandingkan berdasarkan keingingan user dengan cara menceklis bagian yang di inginkan oleh user untuk mendapatkan hasil proses promethee.

Setelah user memilih pilihan salah satu atau semuanya kriteria yang terdapat 6 (enam) kriteria, maka user dapat memperoses data atau kriteria yang dipilih oleh user. Dalan memilih kriteria ini user tidak bisa menghitung atau memproses jika user tidak memilih salah satu atau semua dari kriteria yang sudah disediakan tersebut. Maka user harus memilih salah satu atau semua dari kriteria tersebut. 
TELEMATIKA Vol. 8, No. 1, JULI $2011: 63-74$

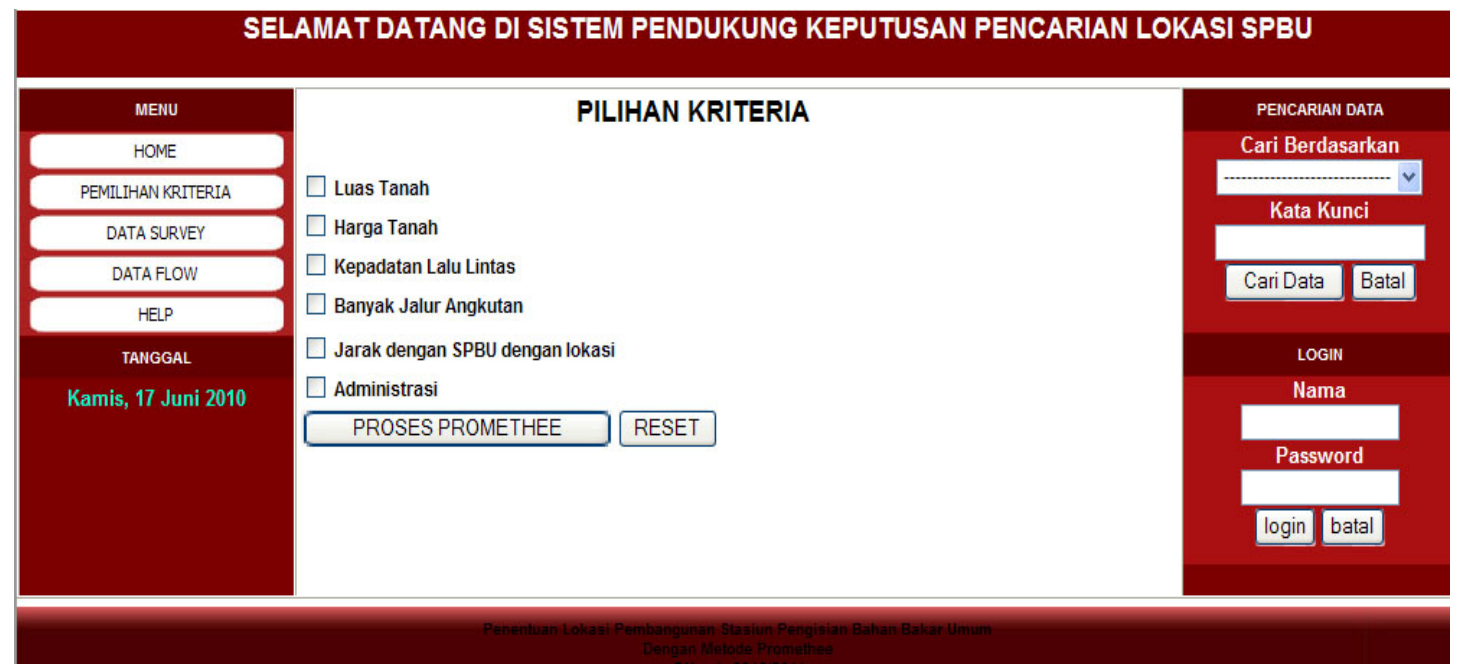

Gambar 4.2 Halaman Pilihan Kriteria promethee

Setelah memilih kriteria maka langkah selanjutnya adalah melakukan proses

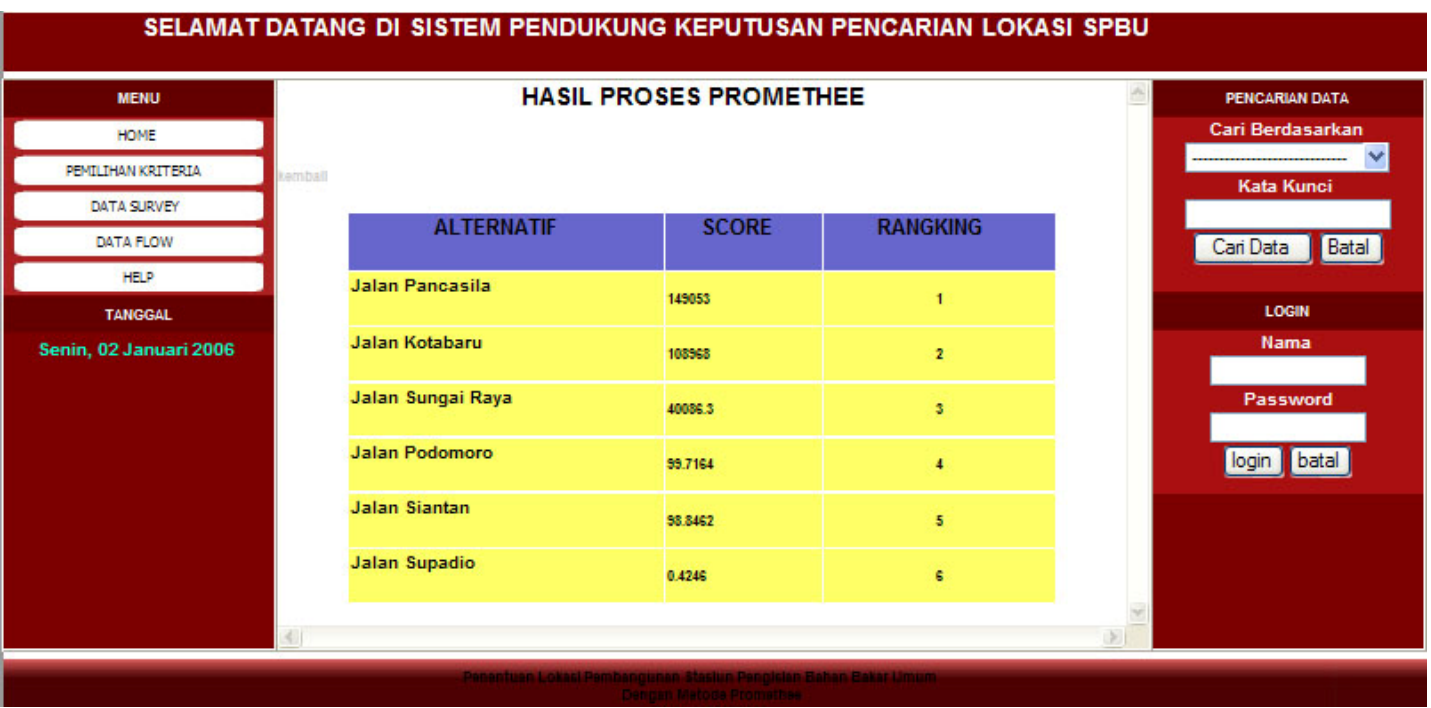

Gambar 4.3 Halaman Hasil Proses promethee

\section{Halaman Admin Input Alternatif}

Tampilan input alternatif pada admin berfungsi untuk mengelolah data alternatif dan data alternatif tersebut akan diproses dan masuk kedalam database, dengan demikian dapat melakukan beberapa perintah dihalam input alternatif ini yaitu : simpan, ubah, dan hapus. 


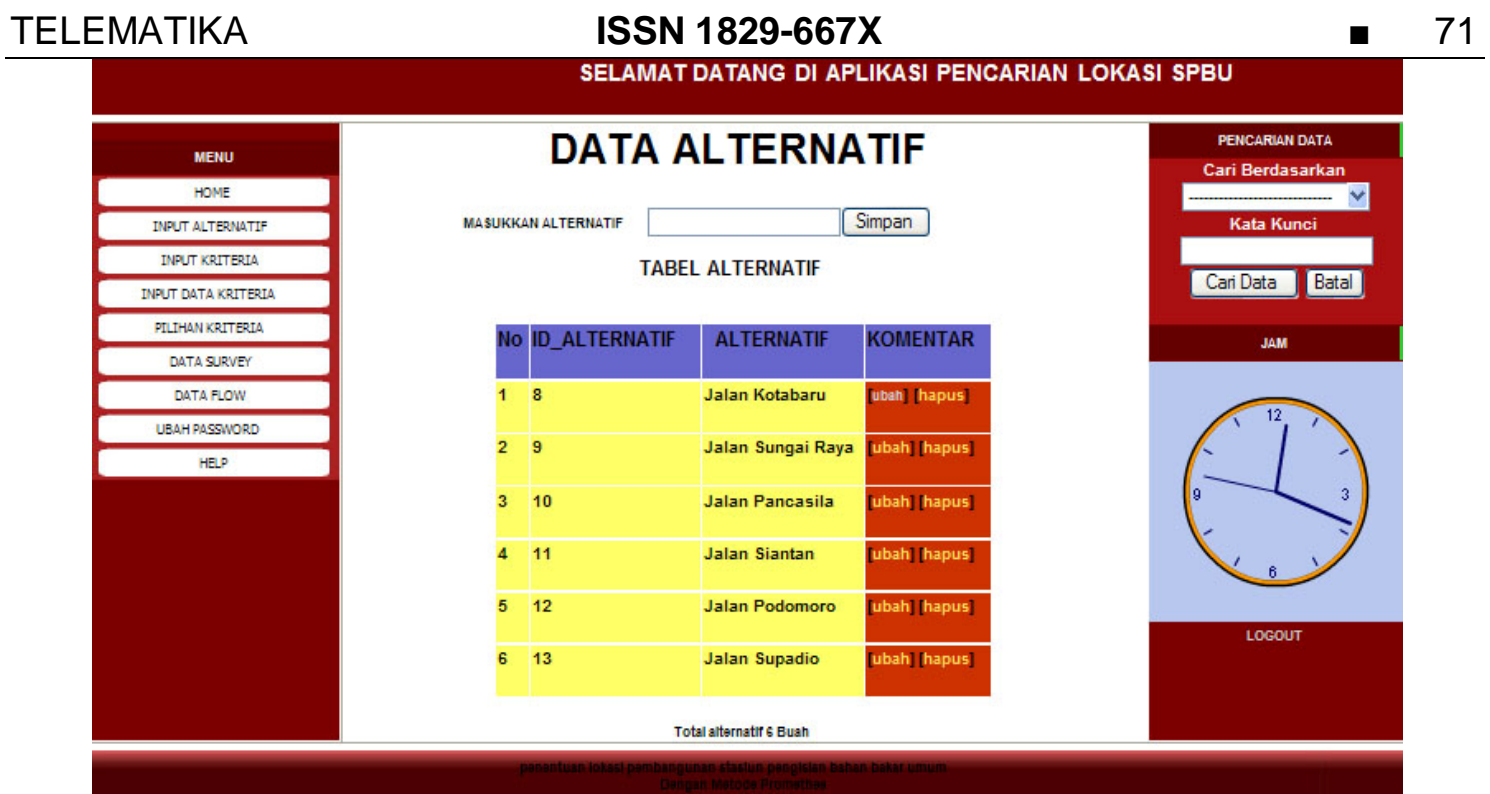

Gambar 4.4 Halaman Admin Input Alternatif

\section{Halaman Admin Input Kriteria}

Halaman input kriteria pada admin berfungsi untuk mengelolah data kriteria, adapun olah data kriteria terdiri dari beberapa komponen yaitu : pilih alternatif yang akan di inputkan untuk kriteria dan kemudian data alternatif tersebut akan dikirimkan ke halaman pilihan kriteria. Dapat kita lihat pada gambar berikut :

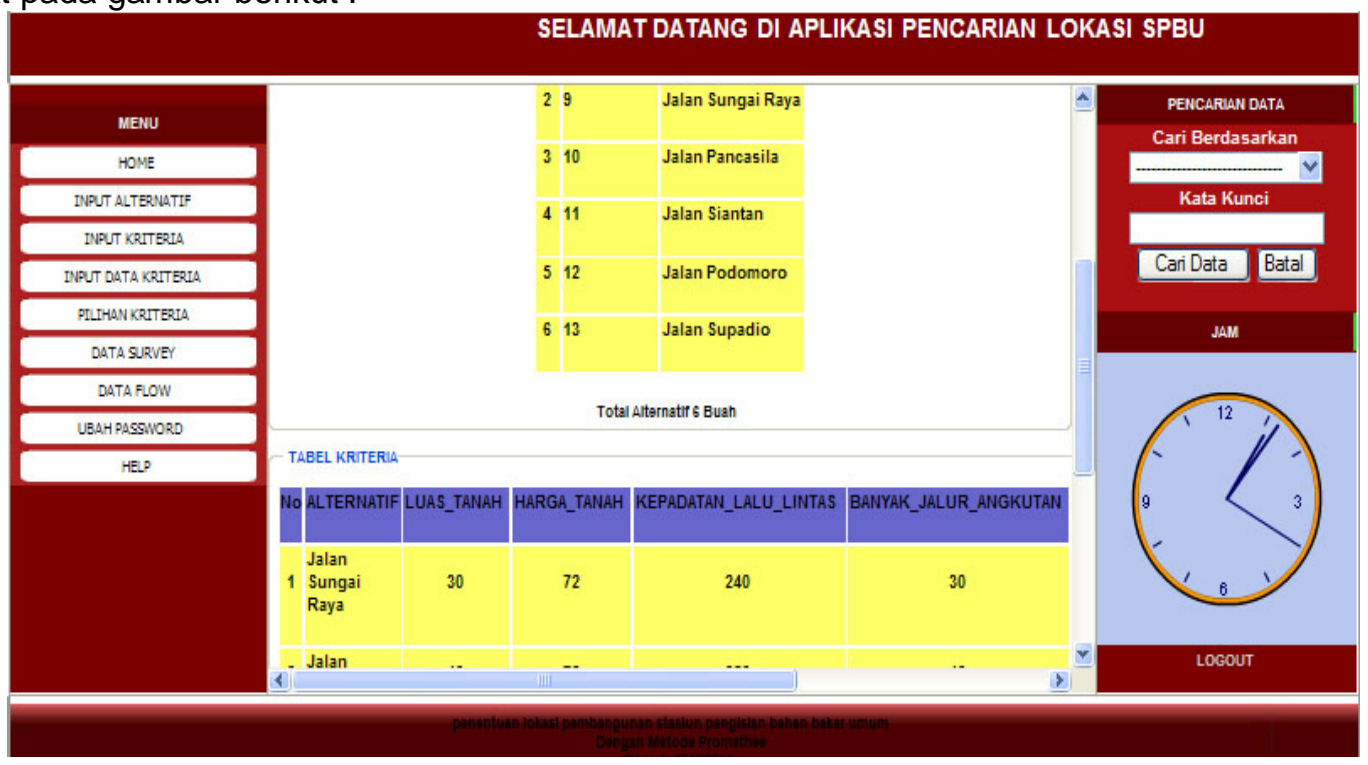

Gambar 4.5 Halaman Admin Input Kriteria

Kemudian setelah proses maka akan muncul daftar pilihan sebagai nilai kriteria dari alternatif yang telah di inputkan. 
TELEMATIKA Vol. 8, No. 1, JULI $2011: 63-74$

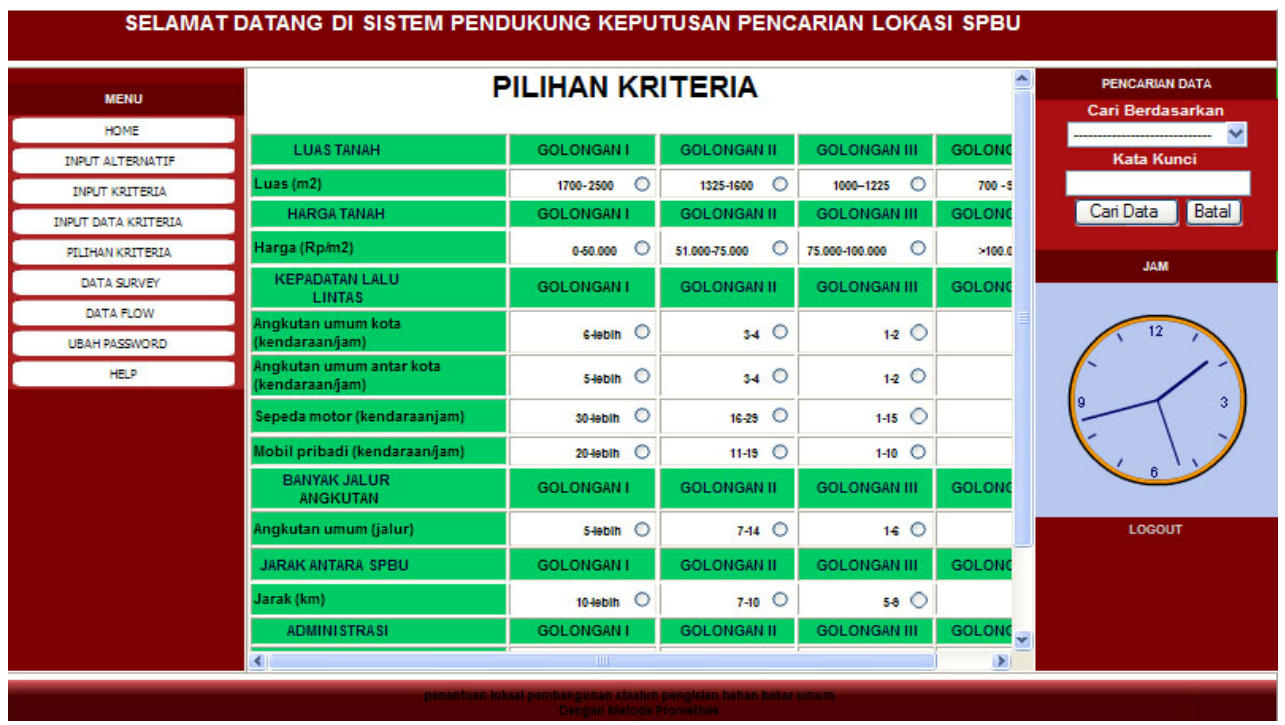

Gambar 4.6 Tampilan Admin Daftar Pilihan Nilai Kriteria

\section{Halaman Admin Input data_kriteria}

Halaman input data_kriteria pada admin berfungsi untuk mengelolah data input data kriteria dari kriteria, yaitu no urut, nama kriteria, kaidah, bobot, tipe preferensi, parameter1, parameter2, dan tampilan ini juga menampilkan data kriteria.

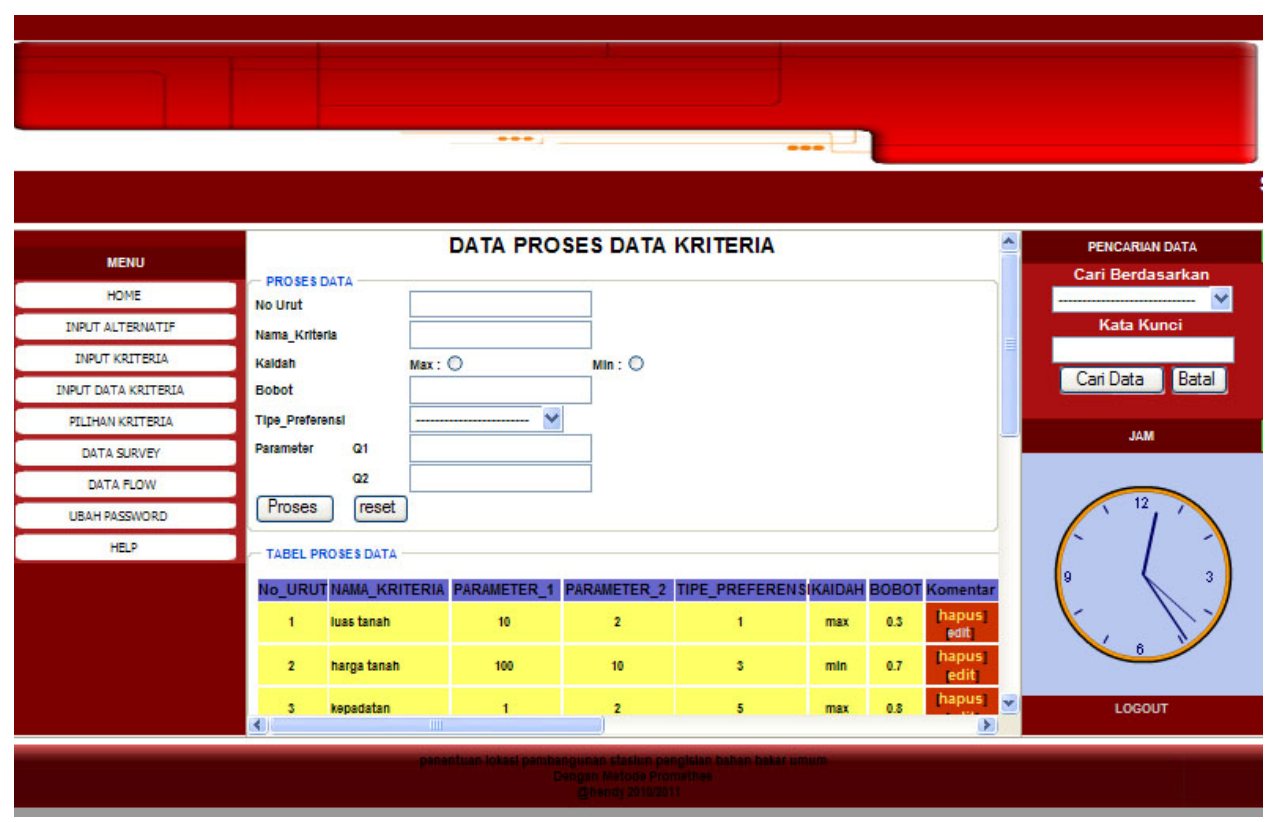

Gambar 4.7 Halaman Admin Input data_kriteria

\section{PENGUJIAN}

Pada tahap pengujian dilakukan perhitungan nilai preferesi masing-masing alternatif yang dilakukan secara berpasangan satu persatu berdasarkan pilihan bentuk tipe preferensi yang telah ditetapkan sebelumnya dan menggunakan dasar perhitungan fungsi preferensi kriteria dari data.

Sebagai contoh perhitungan menual dapat digunakan berdasarkan data kriteria yang telah diinputkan dalam database, kemudian data tersebut dapat dibandingkan dengan alternative yang terdapat dalam database. 
Tabel 4.1 Nilai kriteria untuk masing-masing alternatif

\begin{tabular}{|c|c|c|c|c|c|c|c|c|c|}
\hline \multirow[t]{2}{*}{ Kriteria } & \multirow{2}{*}{$\begin{array}{l}\text { Mini } \\
\text { Max }\end{array}$} & \multicolumn{6}{|c|}{ ALTERNATIF } & \multirow{2}{*}{$\begin{array}{l}\text { Tipe } \\
\text { preferensi }\end{array}$} & \multirow[t]{2}{*}{ parameter } \\
\hline & & A1 & A2 & A3 & A4 & A5 & A6 & & \\
\hline K1 & $\operatorname{Max}$ & 42 & 30 & 42 & 42 & 42 & 43.1 & 1 & - \\
\hline K2 & Min & 84 & 72 & 72 & 60 & 60 & 28.8 & 2 & $q=10$ \\
\hline K3 & $\operatorname{Max}$ & 216 & 240 & 252 & 120 & 186 & 143.8 & 3 & $p=2$ \\
\hline K4 & Max & 30 & 30 & 42 & 20 & 30 & 28.8 & 4 & $q=1, p=2$ \\
\hline K5 & Max & 84 & 84 & 72 & 16 & 84 & 57.6 & 5 & $q=1, p=20$ \\
\hline K6 & Min & 42 & 30 & 8 & 42 & 20 & 431 & 2 & $a=1$ \\
\hline
\end{tabular}

Untuk hasil perhitungan keseluruhan dapat dilihat dari tabel sebagai berikut :

Tabel 4.2 Nilai leaving flow, entering flow, dan net flow

\begin{tabular}{|l|l|l|l|l|l|l|l|l|l|}
\hline Alternatif & A1 & A2 & A3 & A4 & A5 & A6 & $\begin{array}{l}\text { Leaving } \\
\text { flow }\end{array}$ & $\begin{array}{l}\text { Entering } \\
\text { flow }\end{array}$ & $\begin{array}{l}\text { Net } \\
\text { flow }\end{array}$ \\
\hline A1 & - & $\mathbf{1 . 3 3 3}$ & 2.5 & 8.333 & 3.333 & 6.183 & $\mathbf{4 . 3 3 6 4}$ & $\mathbf{0 . 3 8 3 4}$ & $\mathbf{3 . 9 5 3}$ \\
\hline A2 & $\mathbf{0 . 3 3 3}$ & - & 0.833 & 10.333 & 5.167 & 8.35 & 5.0032 & 0.683 & 4.3202 \\
\hline A3 & 0.417 & 0.583 & - & 11.5 & 6 & 9.35 & 5.57 & 0.9666 & 4.6034 \\
\hline A4 & 0.417 & 0.583 & 0.5 & - & 5.167 & 1.817 & 1.6968 & 6.2332 & 4.5364 \\
\hline A5 & 0.167 & 0.333 & 0.417 & 0.417 & - & 3.85 & 1.0368 & 4.05 & 3.0132 \\
\hline A6 & 0.583 & 0.583 & 0.583 & 0.583 & 0.583 & - & 0.583 & 5.91 & 5.327 \\
\hline
\end{tabular}

\section{KESIMPULAN}

Berdasarkan hasil analisis, perancangan, dan implementasi, telah berhasil dibangun sebuah sistem pendukung keputusan sehingga dapat ditentukan keputusan yang objektif. Keputusan (Rangking atau prioritas) yang dihasilkan dari sistem pendukung keputusan untuk menentukan lokasi pembangunan stasiun pengisian bahan bakar umum dengan metode promethee bukanlah suatu keputusan (Rangking prioritas) yang mutlak dimana keputusan akhir tetap ditentukan sendiri oleh User. Jadi sistem pendukung keputusan merupakan suatu program bantu dalam mempertimbangkan suatu pengambilan keputusan. 


\section{DAFTAR PUSTAKA}

Daihani, D, Umar. 2001. Komputerasi Pengambilan Keputusan, PT Elex Media Komputindo, Jakarta.

Fathansyah. 2001. Basis Data, Penerbit Informatika, Bandung.

Klasifikasi SPBU.< http://spbu.pertamina.com/off/spbu.aspx > (22 Januari 2010, accessed 25 Januari 2010).

Suryadi, K. dan A. Ramdhani. 1998. Sistem Pendukung Keputusan, PT Remaja Rosdakarya, Bandung.

Lenawati Mei 2007, Dreamweaver 8 dengan PHP, Penerbit Andi Offset, Madiun.

Nugroho, Munafit, 2006, Tips dan Trik Pemrograman PHP5, Ardana Media, Yogyakarta.

Potensi SPBU.< www.pontianakpost.com > (22 Desember 2009, accessed 5 Januari 2010).

Yulianto, A. 2009. Sistem Pendukung Keputusan dalam Pemilihan Suplier dengan Metode Promethee pada CV. Tri Optic Persada, Skripsi Informatika UPN Yogyakarta. 